\title{
PLAN DZIAŁAŃ KRÓTKOTERMINOWYCH JAKO PRAWNY INSTRUMENT OCHRONY POWIETRZA
}

\section{SHORT-TERM ACTION PLAN AS A LEGAL INSTRUMENT IN THE PROTECTION OF AIR QUALITY}

\section{STRESZCZENIE}

Celem niniejszego artykułu jest dokonanie analizy planów działań krótkoterminowych jako prawnego instrumentu ochrony powietrza w Polsce. W niniejszej pracy przybliżono główne założenia, na których opiera się ten instrument - wprowadzony do polskiego porządku prawnego w związku z implementacją dyrektywy Parlamentu Europejskiego i Rady 2008/50/WE. Przedstawiono w nim również

Magister, doktorantka na Wydziale Prawa, Administracji i Ekonomii Uniwersytetu Wrocławskiego. 
aktualny stan regulacji prawnej w zakresie środków mających służyć zmniejszeniu ryzyka występowania przekroczeń poziomów zanieczyszczeń w powietrzu oraz ograniczeniu skutków i czasu ich trwania. Szczególną uwagę poświęcono niedostatkom omawianej regulacji. Zasygnalizowano, iż - w swoim obecnym kształcie - analizowane przepisy powodować mogą trudności z prawidłową ich wykładnią. $\mathrm{W}$ rezultacie natomiast prowadzić to może $\mathrm{w}$ pierwszym rzędzie do pozbawienia wspomnianych planów skuteczności, a w konsekwencji do niedotrzymania przez Polskę zobowiązań w zakresie poprawy jakości powietrza, wynikających z powołanej wyżej dyrektywy.

\section{Słowa kluczowe}

Prawna ochrona jakości powietrza; plany działań krótkoterminowych; dyrektywa 2008/50/WE; programy ochrony powietrza.

\section{ABSTRACT}

The aim of this article is to analyse a short-term action plan as a legal measure of protecting air quality in Poland. The aforementioned instrument has been implemented into the Polish Environmental Law as a result of obligations imposed by directive 2008/50/EC of the European Parliament and of the Council. This work reviews its main principles and examines current legal regulations in Poland on the subject of short-term measures to be taken to reduce the risk or duration of exceedance of air quality limit values. It indicates the imperfections of this regulation causing problems with its interpretation and preventing short-term action plans from becoming effective instruments protecting air quality. It leads to the conclusion that at current stage the Polish Environmental Law fails to achieve the objectives stated in the aforesaid directive which can cause further deterioration of air quality.

\section{Keywords}

Legal protection of air quality; short-term action plans; directive 2008/50/EC; air protection programmes. 


\section{UWAGI WSTĘPNE}

Polski system ochrony powietrza oparty jest na dwojakiego rodzaju instrumentach prawnych. Z jednej strony zapewnianie tej ochrony następuje poprzez stanowienie generalnych standardów jakości powietrza oraz tworzenie programów naprawczych, mających służyć ich przestrzeganiu. Natomiast w dalszym rzędzie, zgodnie z jego założeniami, osiągnięcie tego celu ma następować poprzez działania polegające na przeciwdziałaniu i kontrolowaniu emisji zanieczyszczeń.

Urzeczywistnianiu ochrony powietrza w pierwszym jej aspekcie służyć mają między innymi programy naprawcze, których generalne przesłanki tworzenia i przyjmowania oraz zasadnicza treść uregulowane zostały w art. 84 Ustawy z dnia 27 kwietnia 2001 r. Prawo ochrony środowiska ${ }^{1}$.

Programy te, z woli ustawodawcy, mają formę aktów prawa miejscowego, tworzonych w celu doprowadzenia do przestrzegania standardów jakości środowiska w przypadkach, w których przewiduje to wspomniana wyżej ustawa lub przepisy szczególne. W myśl art. 84 ust. 2 określają one między innymi naruszone standardy jakości środowiska wraz z podaniem zakresu naruszenia, podstawowe kierunki i zakres działań niezbędnych do przywracania tych naruszonych standardów, zawierają harmonogram rzeczowo-finansowy planowanych działań, wskazują podmioty, wobec których kierowane są obowiązki ustalone w tych programach oraz sposób kontroli i dokumentowania ich realizacji oraz efektów.

Ukształtowanie regulacji dotyczącej programów naprawczych poprzez wyodrębnienie normy o charakterze generalnym, zawierającej podstawowe założenia, na jakich ma się opierać realizowana za pomocą tych programów ochrona zasobów środowiska, i dopełnianie następnie jej treści szczegółowymi przepisami ustawy, odnoszącymi się do ochrony poszczególnych zasobów, każe postawić pytanie o miejsce w tym porządku planów działań krótkoterminowych.

1 T.j. Dz.U. z 2013 r., poz. 1232 ze zm., dalej cyt.: u.p.o.ś. 
Instrumentowi temu poświęcony został art. 92 u.p.o.ś. Zgodnie $\mathrm{z}$ jego treścią, $\mathrm{w}$ brzmieniu nadanym mu przez art. 1 pkt 9 Ustawy z dnia 13 kwietnia 2012 r. o zmianie Ustawy Prawo ochrony środowiska oraz niektórych innych ustaw ${ }^{2}$, w przypadku ryzyka wystąpienia $\mathrm{w}$ danej strefie przekroczenia poziomu alarmowego, dopuszczalnego lub docelowego substancji w powietrzu, zarząd województwa, w terminie 15 miesięcy od dnia otrzymania informacji o tym ryzyku od wojewódzkiego inspektora ochrony środowiska, opracowuje i przedstawia do zaopiniowania - właściwym wójtom, burmistrzom lub prezydentom miast i starostom - projekt uchwały w sprawie planu działań krótkoterminowych. W projekcie tym, w myśl powołanego przepisu, ustalone zostają po pierwsze działania zapobiegawcze, mające na celu zmniejszenie ryzyka wystąpienia takich przekroczeń, po drugie natomiast określane są czynności służące ograniczeniu skutków i czasu trwania przekroczeń już zaistniałych.

\section{PLAN DZIAEAŃ KRÓTKOTERMINOWYCH W PRAWODAWSTWIE UNII EUROPEJSKIEJ - RYS HISTORYCZNY}

Instrument ochrony powietrza $\mathrm{w}$ postaci planu działań krótkoterminowych przewidywała już Dyrektywa Rady 96/62/WE z dnia 27 września 1996 r. w sprawie oceny i zarządzania jakością otaczającego powietrza ${ }^{3}$. Zgodnie z treścią jej art. 7 ust. 3 zdanie pierwsze - Państwa członkowskie zobowiązane były do sporządzenia planu działań wskazujących środki, jakie będą podjęte $\mathrm{w}$ perspektywie krótkoterminowej, w przypadkach gdy zaistniałoby ryzyko przekroczenia wartości dopuszczalnych i/lub progów alarmowych substancji w powie- 
trzu, w celu zmniejszenia tego niebezpieczeństwa i ograniczenia czasu trwania takiego stanu.

Wprowadzenie go do polskiego porządku prawnego miało na celu transpozycję art. 24 dyrektywy Parlamentu Europejskiego i Rady 2008/50/WE w sprawie jakości powietrza i czystszego powietrza dla Europy ${ }^{4}$. Przepis ten uregulował problematykę sporządzania planów, których zadaniem miało być określenie krótkoterminowych działań, jakie mają być podejmowane doraźnie w celu ograniczenia zagrożenia lub też skrócenia czasu występowania przekroczenia czy to jednego, czy też kilku progów alarmowych albo wartości dopuszczalnych i docelowych substancji w powietrzu.

W jego myśl, w przypadku, w którym zaistniałoby zagrożenie, że poziomy zanieczyszczeń w powietrzu przekroczą jeden lub kilka progów alarmowych, wyszczególnionych w załączniku XII do tego aktu, na państwach członkowskich Unii Europejskiej ciążył obowiązek opracowania planów określających krótkoterminowe działania podejmowane $\mathrm{w}$ celu ograniczenia zagrożenia lub skrócenia czasu występowania tego przekroczenia. W sytuacji pojawienia się zagrożenia związanego z przekroczeniem poziomu alarmowego dla ozonu wymóg opracowania takiego planu został nałożony na Państwa członkowskie tylko wtedy, jeżeli uznałyby one, że istnieje znacząca możliwość ograniczenia zagrożenia, czasu jego występowania lub stopnia przekroczenia przy uwzględnieniu warunków geograficznych, klimatycznych i ekonomicznych. Ostatecznie jeżeli owo zagrożenie lub też przekroczenie miałoby dotyczyć co najmniej jednej wartości dopuszczalnej lub wartości docelowej, przepisy dyrektywy nie nakładały żadnego obowiązku w opisanym wyżej zakresie stanowiąc, że stosowne plany działań państwa członkowskie opracowywać będą „w miarę potrzeby”.

Rozwijając powyższe unormowanie $\mathrm{w}$ art. 24 ust. 2 powołanego aktu stwierdzono, że plany te powinny przewidywać efektywne środki służące kontroli - a tam, gdzie to niezbędne zawieszeniu działalności, która przyczynia się do wystąpienia ryzyka przekroczenia wartości dopuszczalnych, docelowych

4 Dz. Urz. UE L 152 z 11.6.2008, s. 1, dalej cyt.: dyrektywa 2008/50/WE. 
lub progów alarmowych. Ponadto wskazano, iż, w zależności od okoliczności danego przypadku, plany te mogą obejmować środki w odniesieniu do ruchu drogowego, prac budowlanych, statków na kotwicy, wykorzystywania zakładów i produktów przemysłowych oraz ogrzewania domowego. W ich ramach rozważeniu podlegałyby również konkretne środki służące ochronie wrażliwych grup ludności, w tym dzieci.

Źródłem idei planów krótkoterminowych, która swoje odzwierciedlenie znalazła w przytoczonych wyżej przepisach dyrektywy, była realizacja podstawowej zasady prawa ochrony środowiska, jaką jest zasada prewencji. Przyjęto bowiem słuszne założenie, iż szkodliwość niektórych pojawiających się w powietrzu substancji jest na tyle duża, że powodują one zagrożenie dla zdrowia ludzi nawet wówczas, gdy przekroczenia ich koncentracji są krótkotrwałe ${ }^{5}$. Jako takie zaś wymagają podjęcia działań zdecydowanie szybszych niż opracowywanie kompletnego i całościowego programu ochrony powietrza ${ }^{6}$.

\section{PLAN DZIAEAŃ KRÓTKOTERMINOWYCH NA GRUNCIE USTAWY PRAWO OCHRONY ŚRODOWISKA}

Polski ustawodawca świadomy był niewątpliwie znaczenia działań doraźnych dla zapewnienia ochrony powietrza przed zanieczyszczeniami. Wyraz tej świadomości dał on już w treści obowiązującego do dnia 25 października 2001 r. art. 32 Ustawy z dnia 31 stycznia 1980 r. o ochronie i kształtowaniu środowiska7 ${ }^{7}$. Właśnie $\mathrm{w}$ tym przepisie, w jego brzmieniu ustalonym Ustawą z dnia 29 sierpnia 1997 r. o zmianie Ustawy o ochronie i kształtowaniu środowiska oraz o zmianie niektórych ustaw ${ }^{8}$,

5 J. Jendrośka, M. Bar, Prawo ochrony środowiska. Podręcznik, Wrocław 2005, s. 775.

6 K. Gruszecki, Prawo ochrony środowiska. Komentarz, Warszawa 2011, s. 127.

7 Tekst pierwotny: Dz.U. z 1980 r. nr 3, poz. 6.

8 Dz.U. z 1997 r. nr 133, poz. 885. 
a następnie Ustawą z dnia 24 lipca 1998 r. o zmianie niektórych ustaw określających kompetencje organów administracji publicznej, w związku z reformą ustrojową państwa9 ${ }^{9}$, przyznał on wojewodzie kompetencję do określenia - w drodze rozporządzenia - alarmowych poziomów stężeń zanieczyszczeń dla terenu województwa lub jego części oraz określenia zakresu działań zmierzających do ograniczenia emisji zanieczyszczeń do powietrza.

Zgodnie z treścią powołanego przepisu rozporządzenie to miało w szczególności regulować tryb i sposób ogłaszania stanów alarmowych, listę jednostek organizacyjnych obowiązanych do ograniczenia lub zakazu emisji, tryb uzgadniania sposobu i zakresu ograniczenia emisji, sposób organizacji i ograniczeń lub zakazu ruchu pojazdów, maszyn i urządzeń napędzanych silnikami spalinowymi na obszarze, na którym ogłoszono stan alarmowy, a także postępowanie organów, instytucji i jednostek organizacyjnych oraz zachowanie się obywateli $\mathrm{w}$ razie ogłoszenia stanu alarmowego. Jego ustanowienie pozostawione zostało uznaniu wojewody, który - w przypadku nieznacznego prawdopodobieństwa wystąpienia przekroczenia poziomów alarmowych zanieczyszczeń w powietrzu - mógł takiego rozporządzenia nie wydawać.

Oprócz powyższego art. 32 ust. 3 Ustawy o ochronie i kształtowaniu środowiska wyposażał wojewodę w jeszcze jedną kompetencję. Mianowicie na jego podstawie organ ten został uprawniony do ogłoszenia stanu alarmowego w przypadku, gdyby z przeprowadzonych analiz i prognoz wynikało, że występująca sytuacja mogła doprowadzić do osiągnięcia lub przekroczenia, określonych w rozporządzeniu, alarmowych poziomów stężeń.

$\mathrm{Na}$ gruncie zastępującej powyższy akt prawny Ustawy Prawo ochrony środowiska, w kwestii opracowywania i uchwalenia planów działań krótkoterminowych ustawodawca wprowadził wymagania idące dalej niż wspomniana już dyrektywa 2008/50/WE. Obowiązek określenia tych planów nałożył on bowiem nie tylko na wypadek pojawienia się ryzyka występowa-

9 Dz.U. z 1998 r. nr 106, poz. 668. 
nia przekroczeń alarmowych poziomów substancji w powietrzu w danej strefie, ale także w przypadku, w którym zaistniałoby ryzyko przekroczeń poziomów dopuszczalnych. Plan taki stanowić miał początkowo wojewoda $\mathrm{w}$ formie rozporządzenia. Następnie, w konsekwencji kolejnych nowelizacji powołanego wyżej przepisu, kompetencję taką przyznano sejmikowi województwa, mającemu przyjmować ten dokument w drodze stosownej uchwały.

Ostatecznego kształtu analizowany przepis art. 92 u.p.o.ś. nabrał na mocy wspomnianej już na wstępie Ustawy nowelizującej z dnia 13 kwietnia 2012 r. W jej art. 1 pkt 9 lit. a) postanowiono, iż plan działań krótkoterminowych będzie sporządzany nie tylko - jak było to do tej pory - w przypadku ryzyka przekroczeń poziomów alarmowych oraz dopuszczalnych, ale także w sytuacji pojawienia się takiego ryzyka dla poziomu docelowego. Powyższa zmiana nastąpiła równocześnie z nowelizacją art. 91 u.p.o.ś. Z mocy art. 1 pkt 7 lit d) wspomnianej wyżej ustawy zmieniającej, do treści art. 91 dodany został ust. 3a, w myśl którego plan działań krótkoterminowych miał odtąd stać się integralną częścią projektu uchwały w sprawie programu ochrony powietrza lub jego aktualizacji, opracowywanego przez zarząd województwa dla stref, w których przekraczane są poziomy dopuszczalne substancji.

Wszystkie te nowo wprowadzone rozwiązania zapewnić miały większą efektywność przewidzianych w polskim porządku prawnym instrumentów ochrony powietrza. Bliższa analiza znowelizowanych przepisów art. 91 oraz art. 92 u.p.o.ś., w zestawieniu $\mathrm{z}$ art. 84 tej ustawy, prowadzi jednak do wniosku, że zmiana treści tych pierwszych nie została przeprowadzona z wystarczającą starannością. Natomiast skutkiem tego jest powstanie wątpliwości co do tak podstawowych zdawałoby się kwestii, jak charakter planów działań krótkoterminowych, przyjmowanych w przypadku ryzyka przekroczenia poszczególnych poziomów substancji w powietrzu, a w rezultacie także co do ich mocy wiążącej.

Argumentując to stanowisko, należy wpierw odwołać się do wspomnianego już art. 84 ust. 1 u.p.o.ś. Przepis ten, jak to 2/2015 już wyżej sygnalizowano, ma charakter przepisu centralnego, 
zawierającego upoważnienie do tworzenia programów naprawczych, będących aktami prawa miejscowego. Jest on następnie uzupełniany przez szereg przepisów szczegółowych, pomieszczonych w dalszej części aktu, określających organy uprawnione do tworzenia takich programów, regulujących procedurę ich przygotowania i stanowienia oraz wskazujących niezbędne elementy, jakie programy takie powinny zawierać.

Jak już wspomniano, zgodnie z jego treścią programy ochrony środowiska tworzone są $\mathrm{w}$ celu doprowadzenia do przestrzegania standardów jego jakości. Opierają się one zatem na założeniu, że standardy te musiały już zostać naruszone. Jak się zdaje to właśnie z procesem ich przywracania, czyli podejmowania odpowiednich działań restytucyjnych już po zaistnieniu przekroczenia danego poziomu substancji, ustawodawca powiązał nadanie im formy aktu prawa powszechnie obowiązującego na danym obszarze ${ }^{10}$.

Standard jakości środowiska, o którym mowa powyżej, jest pojęciem, które na gruncie Ustawy Prawo ochrony środowiska posiada swoją definicję legalną, zawartą w art. 3 pkt 34 . Zgodnie z jego treścią standardem takim jest poziom dopuszczalny substancji lub energii oraz pułap stężenia ekspozycji, które muszą być osiągnięte w określonym czasie przez środowisko jako całość lub jego poszczególne elementy przyrodnicze. Powyższa definicja sprzężona jest z pojęciem standardu jakości powietrza jako jednego z zasobów tego środowiska. To ostatnie zrekonstruować można w oparciu o art. 3 pkt 28 lit. a) ustawy, w którego treści ustawodawca postanowił, iż standardem takim jest dopuszczalny poziom substancji w powietrzu, to jest taki, który ma być osiągnięty w określonym terminie i który po tym terminie nie powinien być przekraczany.

Tymczasem art. 92 u.p.o.ś., regulujący kwestię planów działań krótkoterminowych, stanowi o „wystąpieniu ryzyka” przekroczenia określonych poziomów substancji, czyniąc z za-

10 M. Górski, Nowe regulacje prawne $w$ zakresie ochrony jakości powietrzamonitoring i przywracanie wymaganego stanu jakości powietrza, „Acta Iuris Stetinensis 5. Zeszyty Naukowe Uniwersytetu Szczecińskiego” 2014, nr 823, s. 242. 
istnienia tego ostatniego przesłankę obowiązku opracowania przez zarząd województwa projektu uchwały w sprawie wspomnianego planu.

Powyższe zdaje się przemawiać za tym, że plany działań krótkoterminowych - inaczej niż stanowi o tym ogólny przepis art. 84 ust. 1 ustawy - mają charakter generalnie prewencyjny. Tworzone są zatem w sytuacji, w której - choć istnieje zagrożenie przekroczenia takiego dopuszczalnego czy docelowego poziomu substancji w powietrzu - to samo ono jeszcze się nie zmaterializowało. Konsekwentnie natomiast, że nie doszło do naruszenia standardów jakości środowiska, o których mowa w powołanym wyżej przepisie, a które - co należy w tym miejscu zauważyć - dawałoby możliwość traktowania uchwały obejmującej te programy jako programu naprawczego $\mathrm{w}$ rozumieniu powołanego przepisu ustawy.

Na powyższe trafnie zwraca uwagę M. Górski, który, komentując analizowane unormowanie, konkluduje, iż skutkiem przyjęcia, że plan działań krótkoterminowych nie ma charakteru naprawczego, takiego o jakim mowa w upoważniającym przepisie art. 84 ust. 1, stawałaby się w dalszej kolejności niemożność uznania go za akt prawa miejscowego ${ }^{11}$.

Problem mocy obowiązującej tych planów ujawnia się na tle regulacji art. 91 u.p.o.ś. Jak już wspomniano, standardem jakości powietrza jest poziom dopuszczalny substancji w powietrzu. W przypadku jego przekroczenia, w zależności od tego, $\mathrm{w}$ jakim stopniu miało to miejsce, ustawodawca, w przepisach art. 91 ust. 1-3 wspomnianego aktu prawnego, nakłada na sejmik województwa obowiązek powzięcia uchwały w przedmiocie programu ochrony powietrza. Na podstawie art. 91 ust. 3a ustawy integralną część takiej uchwały, której projekt przygotowuje zarząd województwa, stanowić miałby plan działań krótkoterminowych. Plan ten zatem, bez względu na brzmienie art. 84 ust. 1, przy założeniu spełniania przez jego normy wymogu generalności i abstrakcyjności, musiałby być traktowany w kategoriach aktu prawa miejscowego. 
Niedookreślony pozostaje jednakże los tychże planów, które tworzone być mają w przypadku pojawienia się ryzyka przekroczenia poziomu docelowego substancji w powietrzu, to jest takiego, który - zgodnie z treścią art. 3 ust. 28 lit. b u.p.o.ś. - ma być osiągnięty w określonym czasie, za pomocą ekonomicznie uzasadnionych działań technicznych i technologicznych, w celu unikania, zapobiegania lub ograniczania szkodliwego wpływu danej substancji na zdrowie ludzi lub środowisko jako całość.

W ich przypadku przeszkodą do uznania je za akt prawa miejscowego pozostawałby nie tylko wzmiankowany już wyżej prewencyjny, wyprzedzający zatem przekroczenie poziomu substancji, charakter, ale także i ta okoliczność, że plan ten przewidywać ma działania służące bezpośrednio ograniczeniu skutków i czasu trwania przekroczenia tego właśnie docelowego poziomu. Nie ma natomiast służyć przywracaniu standardów jakości powietrza, jak wymaga tego ustawodawca, w analizowanym już przepisie art. 84 ust. 1 u.p.o.ś. Plan taki, w przeciwieństwie do planu przyjmowanego na wypadek ryzyka przekroczenia poziomu dopuszczalnego, nie stanowi również części uchwały w przedmiocie programu ochrony powietrza ${ }^{12}$.

W doktrynie przeważające jest stanowisko o posiadaniu przez plan działań krótkoterminowych charakteru naprawczego. Za powyższym opowiada się między innymi M. Pchałek, który wprost stwierdza, że plany te są rodzajem programu restytucyjnego w rozumieniu art. 84 u.p.o.ś. Ich celem pozostaje bowiem zawsze doprowadzenie jakości środowiska do standardów. Autor ten zaznacza również, z powołaniem się na orzecznictwo Europejskiego Trybunału Sprawiedliwości, iż środki przyjęte w ramach takich planów dawać powinny w krótkoterminowej perspektywie możliwość ograniczenia do poziomu minimum niebezpieczeństwa przekroczenia dopuszczalnych wartości lub progów alarmowych, a także stopniowe osiągnięcie tych po-

12 Na marginesie powyższego zauważyć należy, iż de lege lata, plan taki mógłby stać się ewentualnie częścią programu ochrony powietrza uchwalanego w przypadku przekroczenia poziomu docelowego. Tymczasem ten ostatni nie jest standardem jakości środowiska, o którym mowa w art. 84 ust. 1 u.p.o.ś. Szerzej zob. M Górski, op. cit., s. 242. 
ziomów, które znajdują się poniżej tych wartości lub progów ${ }^{13}$. Stanowisko w przedmiocie posiadania przez plan działań krótkoterminowych charakteru programu, o którym mowa w art. 84 u.p.o.ś., podziela także B. Rakoczy ${ }^{14}$.

Jak można sądzić, źródłem pojawiających się na tle omawianego uregulowania wątpliwości pozostaje głównie niedbałość ustawodawcy w konstruowaniu przepisów powszechnie obowiązującego prawa - nie natomiast jego racjonalny zamiar pozbawienia planów działań krótkoterminowych statusu aktu prawa miejscowego.

Jak zauważa bowiem M. Górski, tryb przyjmowania tych planów, szczegółowo określony w art. 92 ust. 1-1c u.p.o.ś., został przez ustawodawcę uregulowany w sposób analogiczny do tego, w jakim są przyjmowane programy ochrony powietrza. Znowuż zatem zarząd województwa zobligowany został do przygotowania projektu uchwały w terminie 15 miesięcy od dnia otrzymania odpowiedniej informacji od wojewódzkiego inspektora ochrony środowiska. Projekt ten, podobnie jak projekt uchwały w sprawie programu ochrony powietrza, podlega zaopiniowaniu przez właściwych wójtów, burmistrzów lub prezydentów miast i starostów. W przypadku obu aktów na przedstawienie powyższej opinii organom zakreślony został miesięczny termin, po którego bezskutecznym upływie uznaje się, że właściwy projekt został przez nie zaakceptowany. Sejmik województwa na podjęcie odpowiedniej uchwały ma 18 miesięcy od dnia, w którym otrzymał od wojewódzkiego inspektora ochrony środowiska określoną przepisami ustawy informację. Wyłączeniu z procedury uchwalania planu działań krótkoterminowych uległ w zasadzie jedynie wymóg zapewnienia udziału społeczeństwa w pracach nad nim w przypadku, gdy występuje dopiero ryzyko przekroczenia poziomu alarmowego, dopuszczalnego bądź docelowego substancji w powietrzu ${ }^{15}$.

13 M. Pchałek, w: M. Górski, M. Pchałek, W. Radecki, J. Jerzmański, M. Bar, S. Urban, J. Jendrośka, Prawo ochrony środowiska. Komentarz, Warszawa 2011, s. 362-363.

14 B. Rakoczy, w: Z. Bukowski, E. K. Czech, K. Karpus, B. Rakoczy, Prawo ochrony środowiska. Komentarz, Warszawa 2013, s. 147.

15 M. Górski, op. cit., s. 243-244. 
Następnie uwagę zwrócić należy na treść, jaką zgodnie z upoważnieniem ustawowym powinny zawierać plany działań krótkoterminowych. Odnoszący się do tej kwestii art. 92 ust. 2 stanowi mianowicie, iż w planie takim muszą w szczególności być wskazane: lista podmiotów korzystających ze środowiska, obowiązanych do ograniczenia lub zaprzestania wprowadzania z instalacji gazów lub pyłów do powietrza, sposób organizacji i ograniczeń lub zakazu ruchu pojazdów i innych urządzeń napędzanych silnikami spalinowymi, sposób postępowania organów, instytucji i podmiotów korzystających ze środowiska oraz zachowania się obywateli $\mathrm{w}$ przypadku wystąpienia przekroczeń, a także określony tryb i sposób ogłaszania o zaistnieniu przekroczeń. Jak wynika z powyższego, mające być w nim zawarte obowiązki i ograniczenia kierowane są przede wszystkim do podmiotów znajdujących się poza strukturą administracji.

Uchwalenie planu o takim, jak opisany wyżej zakresie treściowym, daje niewątpliwie asumpt do uznania jego charakteru za wiążący. W rezultacie natomiast do przedsiębrania w oparciu o niego konkretnych czynności, w sytuacjach gdy dokonuje się materializacja ryzyka, na wypadek którego został on przyjęty ${ }^{16}$.

O powyższym przekonuje regulacja art. 92 ust. 1d u.p.o.ś., zgodnie z treścią którego w sytuacji ryzyka wystąpienia w danej strefie przekroczenia poziomu alarmowego, dopuszczalnego lub docelowego substancji w powietrzu na wojewódzkim zespole zarządzania kryzysowego ciąży obowiązek poinformowania właściwych organów o konieczności podjęcia działań określonych planem działań krótkoterminowych.

Przyjęcie w świetle powyższego, iż plany te nie mają wiążącego charakteru, musiałoby automatycznie prowadzić do uznania, że nie istnieje podstawa prawna, na której można by wymagać od adresatów określonych w nich obowiązków i ograniczeń, aby ustanowionych w nim wymagań przestrzegali ${ }^{17}$.

Podobne uwagi poczynić należy zestawiwszy treść art. 92 u.p.o.ś. z jej art. 93. W tym ostatnim przepisie postanowiono,

16 Ibidem, s. 244; Por. również M. Górski, w: Prawo ochrony środowiska, red. M. Górski, Warszawa 2014, s. 239.

17 Por. M. Górski, op. cit., s. 244. 
iż wojewódzki sztab zarządzania kryzysowego ma obowiązek niezwłocznego powiadamiania społeczeństwa oraz podmiotów korzystających ze środowiska, obowiązanych do ograniczenia lub zaprzestania wprowadzania $\mathrm{z}$ instalacji gazów lub pyłów do powietrza, w sposób zwyczajowo przyjęty na danym terenie, o ryzyku wystąpienia przekroczenia poziomu alarmowego, dopuszczalnego lub docelowego substancji w powietrzu oraz o wystąpieniu przekroczenia poziomu alarmowego, dopuszczalnego lub docelowego substancji. Wśród elementów, jakie powinno zawierać wyżej opisane powiadomienie, wymieniono między innymi informację o obowiązujących ograniczeniach i innych środkach zaradczych.

Jak zauważa natomiast M. Pchałek, posłużenie się przez ustawodawcę w powołanym przepisie zwrotem „obowiązujących" nakazuje uznanie, że środki te i wspomniane ograniczenia musiały zostać już wcześniej w jakimś akcie określone. W przypadku wystąpienia ryzyka przekroczenia poziomów zanieczyszczeń w powietrzu aktem takim musiałby być właśnie plan działań krótkoterminowych ${ }^{18}$.

Osobną kwestią, którą w tym miejscu należy poruszyć, pozostaje rzeczywista egzekwowalność obowiązków, jakie możliwe są do nałożenia na dane podmioty $\mathrm{w}$ drodze takich planów. Przywołany już wyżej art. 92 ust. 2 u.p.o.ś. zawiera w tej materii regulację dość ogólną. Szerzej normuje ją, wydane na podstawie upoważnienia zawartego w art. 91 ust. 10 tej ustawy, Rozporządzenie Ministra Środowiska z dnia 11 września 2012 r. w sprawie programów ochrony powietrza oraz planów działań krótkoterminowych, gdzie w Załączniku nr 2 zawarto propozycje działań krótkoterminowych ${ }^{19}$. Regulacja ta odpowiada w zasadzie przykładowemu katalogowi działań, jaki wskazany został w powoływanym już wyżej art. 24 ust. 2 Dyrektywy Parlamentu Europejskiego i Rady nr 2008/50/WE.

I tak w pkt 1 lit. a) wskazanego Załącznika jako przykład takiego działania wskazano czasowy zakaz palenia w kominkach, jeżeli nie stanowią one jedynego źródła ogrzewana miesz-

19 Dz.U. z 2012 r., poz. 1028. 
kań w okresie grzewczym. W obecnym stanie prawnym brak jest jednak możliwości wskazania zarówno sposobu egzekucji tego nakazu, jak też organu odpowiedzialnego za kontrolę nad jego przestrzeganiem.

Te same uwagi odnieść należy do wskazanego w pkt 1 lit. b) kolejnego działania krótkoterminowego w postaci zawieszenia robót budowlanych, uciążliwych ze względu na jakość powietrza.

W pkt 3 Załącznika nr 2 wskazano, iż sposobem redukcji emisji punktowej o charakterze działania krótkoterminowego może być czasowe ograniczenie produkcji w instalacjach mających szczególnie uciążliwy wpływ na jakość powietrza w instalacjach wskazanych w planie działań krótkoterminowych, jako mających największy wpływ na jakość powietrza na danym terenie. Znowuż jednak brak jest po pierwsze możliwości ustalenia, w jakim trybie to ograniczenie produkcji miałoby się odbywać. Po wtóre natomiast powstaje wątpliwość, czy można w takim przypadku mówić o abstrakcyjności konstruowanej w oparciu o powyższe normy prawnej.

\section{ZAKOŃCZENIE}

Wszystkie te mankamenty obowiązujących regulacji w zakresie planów działań krótkoterminowych każą postawić pytanie o to, czy w ich obecnym kształcie stanowią one skuteczny instrument ochrony powietrza w Polsce.

Odpowiedź na nie zdaje się być negatywna.

Skuteczności tej pozbawione one zostają przede wszystkim przez brak starania prawodawcy o precyzję stanowionych norm, powodujący późniejsze trudności z ich wykładnią, a także przez niezapewnienie efektywnych środków prawnych gwarantujących, że ustanowione w tych normach obowiązki będą rzeczywiście wykonywane.

Podobny wniosek płynie zresztą także z całokształtu nowelizacji przepisów z zakresu ochrony środowiska dokonanych na przestrzeni ostatnich kilku lat. Przekonuje o jego trafności cho- 
ciażby okoliczność, iż w 2014 r. samorządowe programy ochrony powietrza zostały zrealizowane w zaledwie $6 \%{ }^{20}$.

Konsekwencje takiego stanu rzeczy, na co wskazuje M. Górski, mogą być dwojakie. Pierwszą z nich będzie pojawienie się zarzutu braku efektywności lub niewystarczającej efektywności implementacji przepisów unijnych, a w rezultacie nałożenie z tego tytułu odpowiednich sankcji. Drugą natomiast dalsze ustawiczne pogarszanie się stanu środowiska w Polsce. Zwłaszcza w szczególnie narażonych na kumulowanie się zanieczyszczeń aglomeracjach ${ }^{21}$.

\section{BIBLIOGRAFIA}

Bukowski Z., Czech E. K., Karpus K., Rakoczy B., Prawo ochrony środowiska. Komentarz, Warszawa 2013.

Górski M., Nowe regulacje prawne w zakresie ochrony jakości powietrza - monitoring i przywracanie wymaganego stanu jakości powietrza, „Acta Iuris Stetinensis 5. Zeszyty Naukowe Uniwersytetu Szczecińskiego" 2014, nr 823.

Górski M., Pchałek M., Radecki W., Jerzmański J., Bar M., Urban S., Jendrośka J., Prawo ochrony środowiska. Komentarz, Warszawa 2011.

Gruszecki K., Prawo ochrony środowiska. Komentarz, Warszawa 2011. Jendrośka J., Bar M., Prawo ochrony środowiska. Podręcznik, Wrocław 2005.

Kuligowski Ł., Oddychamy zapylonym powietrzem, http://prawo.rp.pl/ artykul/1077952.html.

Prawo ochrony środowiska, red. M. Górski, Warszawa 2014.

Kontakt e-mail:

anna.dubowska@prawo.uni.wroc.pl

20 Ł. Kuligowski, Oddychamy zapylonym powietrzem, http://prawo.rp.pl/ artykul/1077952.html [dostęp: 13.04.2015 r.].

${ }_{21}$ M. Górski, Nowe regulacje prawne..., s. 244-245. 